Journal of Applied Business, Taxation and Economics Research (JABTER)

Vol. 1, No. 3, February 2022 (Page: 268-271)

DOI: 10.54408/jabter.v1i3.51

E-ISSN 2808-263X

\title{
Employment Benefits in PT. Jamkrida Banten
}

Rasmin

Bina Bangsa University

Rasminrasmin551@gmail.com

Keywords: Employee Benefits, Observations, Rights and Obligations

\begin{abstract}
The purpose of this study was to find out how the practice of employee benefits at PT Jamkrida Banten. This research method uses literature study and field study. Researchers made direct observations on the object of research. The results showed that PT Jamkrida Banten is a regional company that complies with regulations including the application of accounting. PT Jamkrida Banten applies PSAK 24 regarding employee benefits. With the implementation of PSAK 24 at PT Jamkrida, the rights and obligations of employees and the company become clear.
\end{abstract}




\section{Introduction}

Rewards work Becomes motivation worker the accept job. Workers who earn reward work set in PSAK 24. Rewards Work (employee benefits) are whole shape reward given _ something entity in exchange on services provided by workers _ or for disconnection contract work ( PSAK 24). Rewards work covers reward given _ to worker or the responsibility or recipient benefits and can solved, with payment ( or with provision goods or service), good by direct to worker, husband / wife them, kids or dependents else, or to other parties like company insurance (PSAK 24).

Obligation company about reward work apply for all good company _ company private nor company government including Regional Owned Enterprises (BUMD). PT. Jamkrida Banten as one of the BUMD Banten has : about 50 employees, then PT Jamkrida Banten must also apply PSAK 24 regarding Rewards work. Rewards work covers reward work period short ( wages, salaries, contributions social security, leave annual paid, leave sick paid, share profit and bonus and reward nonmonetary. Rewards post- employment ( reward retirement examples of pensions and lump sum payments at the time of retirement, insurance soul post-work and facilities postemployment health services ). Rewards work period long ( leave paid period long as paid leave big and sabbatical leave example paid leave umrah, hajj), severance pay.

Rewards work is whole shape reward given _ entity in exchange on services provided by workers _ or for termination contract work. Rewards work Another long term is whole reward work Besides reward work period short, reward post work and severance pay. Rewards work period short is reward work Besides from severance pay expected _ will solved whole before two mercy month after end period reporting yearly where workers give service related. Rewards post-work is reward work Besides severance pay and compensation work period short outstanding _ after worker complete contract work. Severance pay is reward given _ in exchange on termination agreement work with worker as consequence from decision entity for dismiss worker before age normal retirement ; or decision worker accept offer reward as exchange on termination agreement work .

The application of PSAK 24 is Case important for company . intentional for no apply reward work in report finance company indicates company hide obligation reward work ( Watung and Pusung , 2017). Purpose writing article this is for knowing application of PSAK 24 at PT. Jamkrida Banten.

\section{Research Method}

Method used _ Writer in composing report Duty end is method descriptive, that is something writing that describes actual situation _ about the object under study . according to Sugiyono (2015) method descriptive defined as method used_for describe or analyze something results study but no used for make more conclusions _ wide. Based on definition according to 
Sugiyono, get it said that method analysis descriptive is method study for make description about situation or existing events, so that method this should held data accumulation .

\section{Results and Discussion}

Rewards Work Period Short aim for arrange accounting and disclosure reward work . Statement this require entity for recognize : Liability When the employee has give service and right get reward work that will paid in the future; danb eban When entity enjoy benefit the resulting economy from services provided by eligible workers _ _ get reward work.

Reward plan classification work consist on rewards program post work, reward program sure, contribution program sure, multi- giver program work. Rewards program post-work is a formal or informal setting in which an entity give reward post-work for one or more workers. Rewards program certain is a reward program post -work that is n't is a premium program sure . Contribution program certain is a reward program post- work where enttas pay dues permanent to entity separate (funds) and not own obligation law or obligation constructive for pay dues more carry on if the funds no have sufficient assets for pay whole reward the work provided by the worker in the period running and period before. Multi-giver program work is a fee program certain or rewards program sure (other than the guarantee program social ) which: brings together assets contributed by several entity that is not under common control ; and use these assets for give reward work to workers who come from more from one entity, with base that level dues and rewards determined without notice identity employing entity _ worker that .

Definition related with liability (asset) reward certain net. The program assets consist of from : Assets owned by the reward fund work long term ; and insurance policy ( not party related ) that fulfills terms. Assets owned by the reward fund work Long -term are assets (other than financial instruments issued ) entity whistleblowers who do not could transferred ) which: is owned by a separate entity (fund) by law from entity reporting and established solely for pay or fund reward work ; and available used only for pay or fund reward work, no could used for pay the entity's debt reporting ( even though ) in state bankrupt ), and not could returned to entity reporting, except in Condition : Fund assets have been sufficient for fulfil whole obligation reward work related to the program or entity the reporter; or Assets returned to entity reporter for replace reward work that has been paid by the entity. The upper limit of assets is Mark now from benefit available economy _ in shape a refund from the program or subtraction future fees _ for the program. Deficit or surplus is ; Present value from obligation reward certain reduced ; Fair value of plan assets ( if there is ). Liability (asset) reward certain net is deficit or surplus, adjusted for every impact to limitation on reward assets certain net to limit on assets. Present value obligation reward certain is Mark now from future payment required _ _ for complete obligation on service worker period running and periods before. Present value in calculation the no reduced with program assets. Fair value is the price will be received for sell an asset or the price will be paid for divert something liability in transaction regular Among market participants 
on measurement. Advantages and disadvantages actuarial is change on Mark now from obligation reward certain as consequence from : Customization experience ( impact from difference Among assumption actuarial beginning with what actual happen ): and Influence change actuarial assumptions .

Entity confess estimated cost _ on payment for profit and bonus if and only if ; Entity own obligation law or obligation constructive now on payment burden the as consequence from past events ; _ and Obligations the could estimated by reliable. Obligation now arise if, and only if entity no own alternative other realistic except do payment. Entity confess liabilities and expenses as big as percentage certain from profit net. Entity possible no own obligation law for pay bonuses. Although thus in a number of case, entity own habit give bonuses. In case this entity own obligation constructive because no own alternative other realistic except pay bonuses. Measurement obligation constructive the reflect possibility existence outgoing workers _ without receive bonuses. Entity could estimate by reliable total obligation law on obligation constructive in the program for profit or bonus if, and only if ; Formal requirements of the program load a formula for determine total reward ; Entity determine amount to be paid before report finance authorized for rise ; or Past practice _ give Proof clear about total obligation constructive entity. Obligations that arise in the program for profits and bonuses are consequence from service worker and not transaction with owner entity . because of that entity confess cost for this profit and bonus as burden and not as distribution profit .

\section{Conclusion}

Insurance policy for day old should taken into account in payment reward post-work employees who retire normally or stop before enter age retirement; Obligations that arise in the program for profits and bonuses are consequence from service workers and not transaction with owner entity ( company). because of that entity confess cost for this profit and bonus as burden and not as distribution profit ; PT. Jamkrida Banten will implement for return profit _ as distribution profit Becomes cost / expense in year 2022 book, which one is basic the calculation refers to to profit net year book 2021 top agreement holder share through the Meeting forum General Shareholders (GMS );

\section{References}

Bond Accountant Indonesia.( 2015). Statement standard accountancy finance . Jakarta: Salemba Four .

Sugiyono . 2015. Method Study Quantitative, Qualitative, and R\&D. Bandung : ALFABETA.

Watung, MN, Nangoi , GB, \& Pusung , RJ (2017). Analysis Application PSAK 24 About Rewards Work at Pt Bank Maybank Indonesia Tbk Kcp Kotamobagu . EMBA Journal : Journal Research Economics, Management, Business and Accounting , 4 (4). 